\title{
Untangling positive and negative biotic interactions: views from above and below ground in a forest ecosystem
}

\author{
Rebecca A. Montgomery, ${ }^{1,3}$ Peter B. Reich, ${ }^{1}$ and Brian J. Palik ${ }^{2}$ \\ ${ }^{1}$ University of Minnesota, Department of Forest Resources, 1530 Cleveland Ave. N., St. Paul, Minnesota 55108 USA \\ ${ }^{2}$ Northern Research Station, USDA Forest Service, 1831 Hwy. 169 E., Grand Rapids, Minnesota 55744 USA
}

\begin{abstract}
In ecological communities, the outcome of plant-plant interactions represents the net effect of positive and negative interactions occurring above and below ground. Untangling these complex relationships can provide a better understanding of mechanisms that underlie plant-plant interactions and enhance our ability to predict population, community, and ecosystem effects of biotic interactions. In forested ecosystems, tree seedlings interact with established vegetation, but the mechanisms and outcomes of these interactions are not well understood. To explore such mechanisms, we manipulated above- and belowground interactions among tree seedlings, shrubs, and trees and monitored seedling survival and growth of six species (Pinus banksiana, Betula papyrifera, P. resinosa, Quercus rubra, $P$. strobus, and Acer rubrum) in mature pine-dominated forest in northern Minnesota, USA. The forest had a moderately open canopy and sandy soils. Understory manipulations were implemented in the forest interior and in large gaps and included removal of shrubs (no interactions), tieback of shrubs (belowground), removal of shrubs with addition of shade (aboveground), and unmanipulated shrubs (both below- and aboveground). We found that shrubs either suppressed or facilitated seedling survival and growth depending on the seedling species, source of interaction (e.g., above- or belowground), and ecological context (e.g., gap or forest interior). In general, shrubs strongly influenced survival and growth in gaps, with more modest effects in the forest interior. In gaps, the presence of shrub roots markedly decreased seedling growth and survival, supporting the idea that belowground competition may be more important in dry, nutrient-poor sites. Shrub shade effects were neutral for three species and facilitative for the other three. Facilitation was more likely for shade-tolerant species. In the forest interior, shrub shade negatively affected seedling survival for the most shade-intolerant species. For several species the net effect of shrubs masked the existence of both positive and negative interactions above and below ground. Our results highlight the complexity of plant-plant interactions, demonstrate that outcomes of these interactions vary with the nature of resource limitation and the ecophysiology of the species involved, and suggest that ecological theory that rests on particular notions of plant-plant interactions (e.g., competition) should consider simultaneous positive and negative interactions occurring above and below ground.
\end{abstract}

Key words: competition; Corylus cornuta; facilitation; North American pine forest; plant species interactions; positive and negative effects; shade tolerance.

\section{INTRODUCTION}

Plant-plant interactions are pervasive in terrestrial ecological systems and central to understanding processes of individual growth, demography, community assembly, succession, and biogeochemical cycling (Connell 1983, Schoener 1983, Callaway 1995, Scholes and Archer 1997, Armas and Pugnaire 2005). Plant-plant interactions can be positive or negative (Callaway and Walker 1997). Negative interactions have been more intensely studied than positive interactions and involve processes such as resource competition (Tilman 1982,

Manuscript received 12 September 2009; revised 17 March 2010; accepted 14 April 2010. Corresponding Editor: J. J. Battles.

${ }^{3}$ E-mail: rebeccam@umn.edu
Tilman 1985, Goldberg 1987, Casper and Jackson 1997), mechanical interference (Clark and Clark 1991, FarrisLopez et al. 2004), alteration of soil microbial communities (Klironomos 2002), changes in the soil chemical environment (Callaway and Ridenour 2004), and increases in pathogen and insect pressure (Holt 1977, Augspurger and Kelly 1984, Connell 1990). Positive interactions include processes such as microclimate amelioration (Cater and Chapin 2000, Maestre et al. 2003), hydraulic lift (Ludwig et al. 2004, Zou et al. 2005), alteration of soil microbial communities (Klironomos 2002), and nutrient enrichment (Callaway et al. 1991, Belsky 1994).

The processes outlined above act simultaneously, and thus the outcome of plant-plant interactions represents the net effect of both positive and negative interactions (Callaway and Walker 1997, Scholes and Archer 1997, 
Bruno et al. 2003, Maestre et al. 2003, Dickie et al. 2005, Maestre et al. 2009). Moreover, plants interact above and below ground, and such interactions could theoretically include all combinations of positive, negative, or neutral effects (Shirley 1945, Coomes and Grubb 1998, Pugnaire and Luque 2001). For example, roots foraging for water or nutrients could reduce belowground resource availability for neighbors. Alternatively, root exudates may enhance microbial communities and increase nutrient availability. At the same time, the stems and leaves of one plant may shade a neighbor, reducing light availability, but ameliorating high temperatures, such that the net effect is neutral (Pugnaire and Luque 2001, Valladares et al. 2008). Untangling these interactions is a considerable challenge, but one that furthers our understanding of mechanisms that underlie plant population and community dynamics.

Tree regeneration and forest dynamics result from interactions between seedlings, the abiotic environment, and already established vegetation (e.g., adult trees, shrubs, herbs, etc.). Interactions between seedlings and adults have been much studied (e.g., gap phase regeneration [Janzen 1970, Brokaw 1985]), whereas interactions between seedlings and understory vegetation are less well understood. In a number of forest ecosystems, there is evidence for an increase in the prevalence of dense understories hypothesized to result from anthropogenic increases in canopy disturbance coupled with altered herbivory or fire regimes (Royo and Carson 2006). These dense layers, composed of shrubs, ferns, or bamboos, have the potential to reduce tree regeneration, alter species composition, and impact patterns of forest succession and floristic diversity.

What mechanisms underlie interactions between tree regeneration and understory vegetation? Most studies cite competition or allelopathy, but few have tested mechanisms of interaction using manipulative experiments. Even fewer have separated above- and belowground interactions under contrasting conditions, such as in gaps and forest interior (Dillenburg et al. 1993, Horsley 1993, Schnitzer et al. 2005, Chen et al. 2008, Toledo-Aceves and Swaine 2008).

Neutral or negative interactions appear to dominate shrub-tree seedling interactions in closed-canopy forest. Dense understory vegetation decreases light availability near the forest floor (Horsley 1993, Lorimer et al. 1994, Messier et al. 1998, Montgomery 2004, Bartemucci et al. 2006), and removal of understory vegetation generally increases nutrient and water availability (Shirley 1945, Messier 1993, Lindh et al. 2003, Harrington 2006). Variation in understory resource availability influences regeneration (Beaudet and Messier 1998, Walters and Reich 2000, Montgomery and Chazdon 2002, Machado et al. 2003), but the relative importance of above- vs. belowground interactions is poorly understood. There is considerable evidence from studies of adult tree-seedling interactions that increases in water and/or nutrient availability in the forest understory can increase seedling growth and/or survival (Burslem et al. 1995, Walters and Reich 1996, Coomes and Grubb 2000, Walters and Reich 2000, Machado et al. 2003); however, whether understory vegetation has similar effects is unknown. Given that light is considered most limiting in the forest understory, aboveground interactions may dominate. For example, in North American temperate forests, ferns decrease seedling survival and growth largely through reduced light availability and altered light quality (Horsley 1993, George and Bazzaz 1999a, b). However, the nature of these interactions may also depend on shade tolerance. Shading by shrubs may be neutral for shade-tolerant species and negative for shade-intolerant species. Indeed, in a temperate forest in New Hampshire, removal of an understory shrub led to significantly higher seedling growth of less shadetolerant species (negative interaction) but no change in growth for the most shade-tolerant tree species (neutral interaction [Fagan and Peart 2004]).

Both positive and negative interactions may be important in gaps. Several studies that examined interactions of seedlings with their non-tree competitors found negative effects on seedling survival and growth that were largely due to the belowground interactions (Dillenburg et al. 1993, Davis et al. 1998, Schnitzer et al. 2005). Other experiments, however, showed little or no effect of belowground interactions on seedlings (Ricard et al. 2003). The relative importance (and even direction) of above- and belowground interactions may depend on site conditions. For example, belowground competition may be more important in dry, nutrient-poor sites, whereas aboveground shading could be more important on moist, nutrient-rich sites (Putz and Canham 1992, Coomes and Grubb 1998). Moreover, though gaps are often considered favorable for plant growth, they also impose unfavorable abiotic stresses such as high vapor pressure deficits and high temperatures. Alleviation of abiotic stress could shift interactions from negative to positive, especially on sites with poor soils (Bertness and Callaway 1994) and for shade-tolerant species. Evidence for such positive interactions is abundant in semi-arid contexts (Flores and Jurado 2003, Pugnaire et al. 2004, Gomez-Aparicio et al. 2005), but limited in forested ecosystems (Cater and Chapin 2000, Heinemann and Kitzberger 2006, Pecot et al. 2007).

To explore the nature and mechanisms of shrub-tree seedling interactions, we conducted a field experiment that separated interactions into above- and belowground components. We examined how above- and belowground interactions in closed-canopy and gap environments influence resource availability, seedling growth, and seedling survival of six common North American tree species (Pinus resinosa, Pinus banksiana, Pinus strobus, Quercus rubra, Acer rubrum, Betula papyrifera). We predicted that the nature and extent of shrub-seedling interactions would depend on ecological context (e.g., gaps vs. forest interior) and life history (e.g., shade tolerance). We hypothesized that (1) 
aboveground interactions are neutral or negative in closed-canopy forest, (2) aboveground interactions are neutral, negative, or positive in gaps depending on shade tolerance (Bertness and Callaway 1994, Callaway and Walker 1997), (3) belowground interactions are neutral or negative in closed-canopy forest and gaps, and (4) negative interactions shift from predominantly aboveground in closed-canopy forest to predominantly belowground in gap sites because of shifts in the relative resource limitation across that contrast (Bloom et al. 1985, Tilman 1985, Givnish 1988, Maestre et al. 2009).

\section{Methods \\ Study area}

We conducted the experiment in largely single-cohort monotypic red pine forests in the Chippewa National Forest in north-central Minnesota, USA. The site has a cold temperate climate with mean annual temperatures of $3.9^{\circ} \mathrm{C}$ and mean annual precipitation of $70.0 \mathrm{~cm}$. The study area contains outwash and ice contact landforms characterized by deep sand parent materials. Soils are excessively to well-drained nutrient-poor loamy sands. Soil analysis of the $0-20 \mathrm{~cm}$ mineral horizon of an adjacent experimental forest indicate $\mathrm{pH}$ of 5.5 , total soil $\mathrm{N}$ of $1.12 \mathrm{Mg} / \mathrm{ha}$, and total soil $\mathrm{P}$ of $0.64 \mathrm{Mg} /$ ha (Bray's extraction [Alban 1974]). The forest overstory is dominated by red pine ( $90 \%$ of total basal area) with smaller numbers of Pinus strobus (eastern white pine), Acer rubrum (red maple), Populus tremuloides (trembling aspen), Populus grandidentata (big-tooth aspen), Betula papyrifera (paper birch), Abies balsamea (balsam fir), Picea glauca (white spruce), Quercus rubra (northern red oak), and Q. macrocarpa (bur oak). The understory is dominated by Corylus cornuta (beaked hazel) and Amelanchier spp. (saskatoon).

Forests in the study area were estimated to be $\sim 85$ years old, broadly even-aged, and naturally regenerated after early 20 th century logging and wildfire. Forests have a moderately open canopy with an average basal area of trees $>10 \mathrm{~cm} \mathrm{dbh}$ of $36 \mathrm{~m}^{2} / \mathrm{ha}$ (Atwell et al. 2008) and canopy light transmittance of $\sim 10 \%$ (R. A. Montgomery, unpublished data). In winter 2002/2003, stands were logged as part of a large-scale experiment aimed at increasing structural complexity and species diversity in red pine ecosystems (Palik et al. 2003, Atwell et al. 2008). The overstory treatments included a thinning, with residual trees dispersed evenly throughout the stand and two aggregate or patch cuts that left 0.1ha gaps or 0.3 -ha gaps in a forest matrix. There were four replicate blocks. The experiment presented here was conducted in small plots established in the uncut control and 0.3 -ha gap treatments.

\section{Experimental design}

In spring 2003, we planted seedlings into plots in which overstory and shrub cover was manipulated. In this manuscript, we use the term "seedling" instead of "sapling" based on a forester's definition that saplings are stems $>2.5 \mathrm{~cm}$ but $<10 \mathrm{~cm} \mathrm{dbh}$. To separate above- vs. belowground interactions, we used three experimental shrub removal treatments and an unmanipulated control (shade + roots). To reduce both above- and belowground interactions from shrubs, we clipped all shrubs at ground level (shrubs absent). To reduce belowground but maintain aboveground interactions, we clipped all shrubs at ground level and installed 30\% neutral shade cloth on pve frames situated above plots (shade alone; see Plate 1). The $30 \%$ value was estimated from a priori measurements of shrub shading. The spectral quality of light below the shade cloth differed from that below the green leaves of the shrubs. We calculated R:FR of the shade cloth as 0.99 . We note the difficulty of manipulating R:FR in field experiments: the traditional approach uses plastic films that exclude rainfall. Moreover, there is little evidence that differences in spectral quality affect biomass accumulation in tree seedlings (Kitajima 1994). To reduce aboveground but maintain belowground interactions, we used string to pull shrubby vegetation away from the crowns of the planted seedlings, reducing shading by shrubs (roots alone). Our tieback approach altered the aboveground architecture of the shrubs, which may have led to a reduction in belowground resource use. However, it is likely this treatment reduced interactions much more above than below ground. The four shrub treatments were implemented in two overstory conditions: the center of 0.3 -ha gaps and closed-canopy forest. For each treatment, there were 20 replicate plots spread evenly across the four blocks ( 4 blocks $\times 2$ overstory $\times 4$ shrub treatments $\times 5$ plots $=160$ plots total). There was only one experimental plot in any particular gap (i.e., we worked in 80 0.3-ha gaps). Shrub treatments were assigned randomly to candidate gap and closed forest locations.

Each plot had four individuals of each of six common species: red pine (Pinus resinosa), jack pine (Pinus banksiana), eastern white pine (Pinus strobus), red maple (Acer rubrum), northern red oak (Quercus rubra), and paper birch (Betula papyrifera). Hereafter, we refer to these species by their common names. Seedlings were planted on a $4 \times 6$ grid with $\sim 0.5 \mathrm{~m}$ between individuals (e.g., $2 \times 3 \mathrm{~m}$ plots). Evergreen and deciduous species were alternated across the grid (e.g., row $1=$ evergreen, deciduous, evergreen, deciduous) and species within leaf habit were planted randomly. This spacing was sufficient to minimize interactions between planted seedlings especially in the early years of the project, based on evidence from a density experiment on similar soils and climate (Boyden et al. 2009). For the clipped treatment, all woody upright vegetation was clipped at the base every three weeks during the growing season. Clipped material was discarded outside the plot to avoid nutrient enrichment from decaying leaf litter. This intensity of clipping was designed to minimize the effect of resprouting by shrubs. After the first year, there was little regrowth of shrubs in the plots, and clipping frequency was reduced to 2-3 times per season. Tieback treatments were implemented early in the growing 
season and augmented as necessary due to shoot growth of shrubby vegetation. To assess effects of treatments on shrubs, we measured shrub density annually. Beaked hazel was the most common shrub in the sites, although several of the large gap areas had prolific growth of various Rubus species or resprouting big-tooth aspen, which we treated as "shrubs." We also scored plots for grass/sedge cover $(>50 \%=1$ and $<50 \%=0)$.

\section{Species selection and planting information}

Species were chosen based on vegetation surveys conducted in 2002, prior to implementation of experimental treatments. They represent the most common tree species in our study area as well as important common species in the Great Lakes region and beyond. The species differ in light requirements for regeneration, allowing examination of the impact of shade tolerance on species responses. Shade tolerance rankings order species from most $($ rank $=5)$ to least $($ rank $=1)$ as follows: red maple $(3.44 \pm 0.23$; mean $\pm \mathrm{SE})$, eastern white pine $(3.21 \pm 0.2)$, northern red oak $(2.75 \pm 0.18)$, red pine $(1.89 \pm 0.21)$, paper birch $(1.54 \pm 0.16)$, and jack pine (1.36 \pm 0.33 [Niinemets and Valladares 2006]). Seedlings were grown in nurseries in Minnesota and Wisconsin from local seed sources and planted as bare rootstock. Seedlings were 2-3 years old at the time of planting. All seedlings were protected from browse each fall using PlantSkydd deer repellent (Tree World Plant Care Products, St. Joseph, Missouri, USA). Browse was scored as present or absent during survival and growth surveys. Less than $5 \%$ of seedlings were browsed during the experiment, suggesting that the deer repellent was quite effective.

\section{Resource availability}

To evaluate the effects of experimental treatments on resource availability, we measured light and nutrient availability in all plots. We measured light availability annually during the growing season (June-August) using a LAI-2000 Plant Canopy Analyzer (LICOR, Lincoln, Nebraska, USA) or a sunfleck ceptometer (Decagon Devices, Pullman, Washington, USA). Sensors were used in paired mode, with one sensor located in an open clearing serving as the above-canopy sensor and another sensor taking readings at individual plots. This approach allowed calculation of the percentage transmittance of light to the focal seedlings. Instantaneous measures of the percentage of diffuse transmittance are effective estimates of seasonal light environment (Parent and Messier 1996, Machado and Reich 1999). Measurements were made on uniformly overcast days or at dawn and dusk directly above the crowns of planted seedlings once per growing season. In plots where seedlings differed strongly in height or where shrub cover was not uniform, several measurements that encompassed that variation were averaged. We measured light in 2003, 2004, and 2005. We tried to mount our above-canopy sensor within $500 \mathrm{~m}$ of our sample plots; however, this was not always possible. Mismatch in sky conditions between above and below canopy site can lead to error. We believe such measurement error was small, as data were highly correlated from year to year (e.g., 2003 vs. 2004, $r^{2}=0.91 ; 2004$ vs. $2005, r^{2}=$ $0.88)$.

Nutrient availability was assessed using ion exchange resins. Resins exchange $\mathrm{NO}_{3}{ }^{-}, \mathrm{PO}_{4}{ }^{-}$, and $\mathrm{NH}_{4}{ }^{+}$ providing a general assessment of inorganic nutrient availability. We enclosed $\sim 3 \mathrm{~g}$ of resin in a small bag made of nylon stocking and placed two bags in each plot in the mineral soil layer ( $\sim 5 \mathrm{~cm}$ depth). Resin bags were installed in the field in May and removed in late September/early October of 2003, 2004, and 2005. In the laboratory, resin bags were rinsed in deionized water and air-dried. The resin beads were removed from their bags, weighed, and extracted with $2 \mathrm{~mol} / \mathrm{L} \mathrm{NaCl}$ in 0.1 $\mathrm{mol} / \mathrm{L} \mathrm{HCl}$. Extractant was analyzed on a Lachat QuikChem 800 Automated Ion Analyzer (Hach Company, Loveland, Colorado, USA) at the analytical laboratory of the USDA Forest Service, Northern Research Station, Grand Rapids, Minnesota. This approach yields nutrients on a per gram resin basis. Similar to our estimates of light, resin available nutrients were highly correlated from year to year. Our resin bag nutrient assay is reflective of both supply and demand: greater nutrients may reflect reduced demand or enhanced supply. Since we don't know the exact mechanism, we consider our assay a measure of potential nutrient availability to the roots of a small seedling.

\section{Seedling measurements}

In summer 2003, immediately after planting, we measured diameter and height of each seedling. An initial harvest of 10 individuals of each species was used to develop regression equations to estimate initial aboveground biomass of each planted seedling for use as a covariate in analyses of treatment effects on seedling biomass. The best fit model for each species was based on initial seedling diameter $\left(R^{2}\right.$ ranged from 0.38 to 0.92 with 4 of 6 species $>0.80)$. Species differed in initial aboveground biomass: red maple $(0.52 \pm 0.05 \mathrm{~g})$, eastern white pine $(2.92 \pm 0.45 \mathrm{~g})$, northern red oak $(2.40 \pm 0.31 \mathrm{~g})$, red pine $(3.86 \pm 0.62 \mathrm{~g})$, paper birch $(1.22 \pm 0.13 \mathrm{~g})$ and jack pine $(3.54 \pm 0.43 \mathrm{~g})$. In fall 2003, summer 2004, spring and summer 2005, and spring and fall 2006, we censused seedling survival. In fall 2006, aboveground biomass of all living seedlings was harvested. Harvested seedlings were separated into leaves and stems, dried at $70^{\circ} \mathrm{C}$, and weighed.

\section{Statistical analysis}

We analyzed percentage transmittance data from 2005 (most complete census), average total resin available $\mathrm{N}$ and P across years (2003, 2004, and 2005) and shrub density (2004, 2005, and 2006) using a split-plot ANOVA for block $(r)$, overstory treatment $(i)$, shrub 
treatment $(j)$ and plot $(k)$. The form of the model was

$$
\begin{aligned}
Y_{r(i j k)} & =\mu+\alpha_{i}+\eta_{r(i)}+\beta_{j}+(\alpha \beta)_{i j}+\varepsilon_{r(i j k)} \\
\eta_{r(i)} & \sim \mathcal{N}\left(0, \sigma_{\mathrm{s}-\mathrm{p}}^{2}\right) \\
\varepsilon_{r(i j k)} & \sim \mathcal{N}\left(0, \sigma_{\text {error }}^{2}\right) .
\end{aligned}
$$

The subscript of $\sigma^{2}$, "s-p," stands for "split-plot."

Shrub density was analyzed only in the shade + roots and roots alone treatments, since density in plots where shrubs were clipped (shade alone and shrubs absent) was zero after the first year of intensive clipping. We analyzed yearly censuses of grass and sedge cover using logistic regression with overstory and shrub treatments as main effects. We analyzed final seedling biomass using a split-split plot ANCOVA for block $(r)$, overstory treatment $(i)$, shrub treatment $(j)$, plot $(k)$, tree species $(l)$, and individual $(m)$. Initial biomass was used as a covariate to account for differences among individuals in initial size. Both initial and final biomass were $\log _{10^{-}}$ transformed to achieve normality. The form of the model was

$$
\begin{aligned}
& \log _{10} Y_{r(i j k l m)}= \mu+\theta \log _{10} y_{r(i j k l m)}+\alpha_{i}+\eta_{r(i)} \\
&+\beta_{j}(\alpha \beta)_{i j}+\xi_{r(i j k)}+\gamma_{l}+(\alpha \gamma)_{i l} \\
&+(\beta \gamma)_{j l}+(\alpha \beta \gamma)_{i j l} \varepsilon_{r(i j k l m)} \\
& \eta_{r(i)} \sim \mathcal{N}\left(0, \sigma_{\mathrm{s}-\mathrm{p}}^{2}\right) \\
& \xi_{r(i j k)} \sim \mathcal{N}\left(0, \sigma_{\mathrm{s}-\mathrm{s}-\mathrm{p}}^{2}\right) \\
& \varepsilon_{r(i j k l m)} \sim \mathcal{N}\left(0, \sigma_{\text {error }}^{2}\right) .
\end{aligned}
$$

The subscripts of $\sigma^{2}$, "s-p" and "s-s-p," stand for "split-plot" and "split-split-plot," respectively.

When interactions were significant, we ran separate analyses by species and used contrasts to test hypotheses about the effect of overstory and shrub treatments. For survival, we first fit proportional hazards models to the full data set (species, overstory, shrub as main effects, and all interactions). Since the proportional hazards model neither characterizes differences among the four shrub treatments nor distinguishes between root and shade effects, we also parameterized species-specific proportional hazards models and used the KaplanMeier approach to analyze pairwise comparisons of shrub treatments for each species. For Kaplan-Meier pairwise comparisons, we tested for significant differences with log-rank and Wilcoxon tests.

\section{Results}

\section{Shrub and grass response}

Excluding two plots with extremely high density of raspberry, shrub density in unclipped plots (shade + roots and roots alone) ranged from $<1$ to $35 \mathrm{stems} / \mathrm{m}^{2}$. There was no significant difference in density between those two treatments or between plots in gap and forest

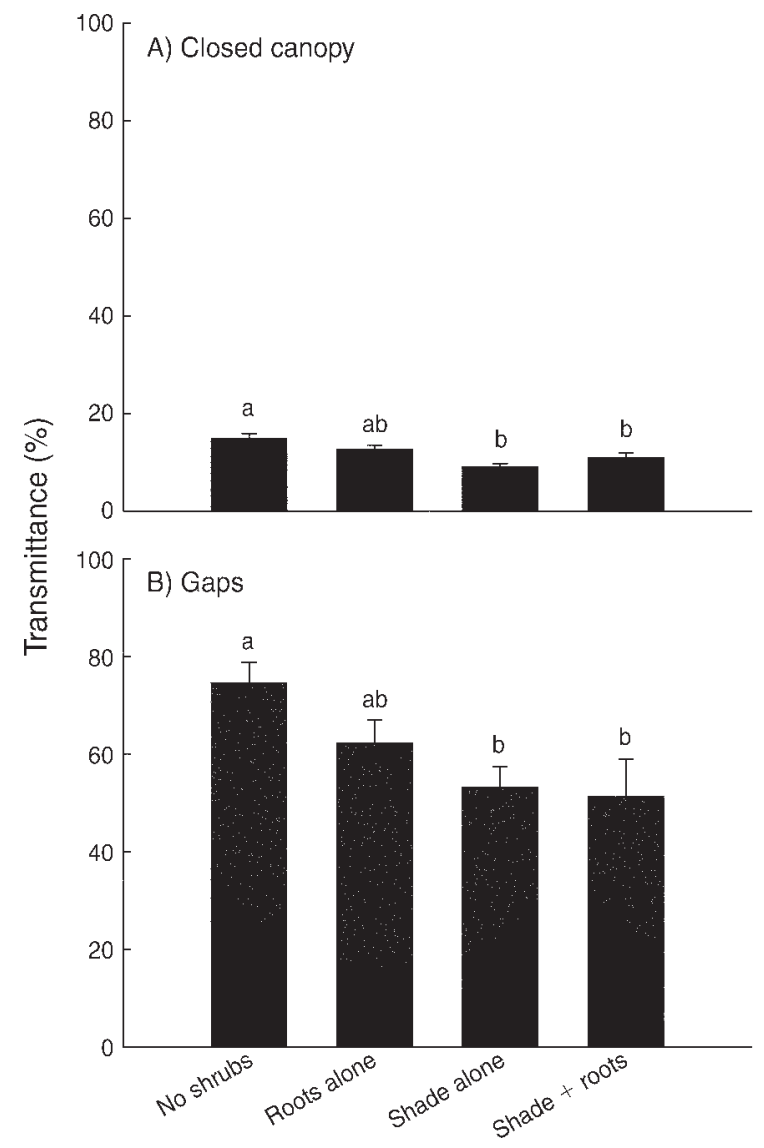

FIG. 1. Light availability (mean + SE) measured as percentage of diffuse transmittance in four experimental shrub manipulations in (A) closed canopy and (B) centers of 0.3-ha gaps in red pine forest in northern Minnesota, USA. Experimental manipulations include shrub removal by clipping (shrubs absent), shrub removal by clipping and addition of shade cloth (shade alone), tieback of shrubs (roots alone), and unmanipulated shrubs (shade + roots). Within each panel, bars with different letters are significantly different using contrasts $(P<0.05)$.

interior. Shrub density did change through time. In 2004, one year after treatments were implemented, there were on average 5.4 individuals $/ \mathrm{m}^{2}$ in forest interior and 4.2 individuals $/ \mathrm{m}^{2}$ in gaps. By 2005 , density had increased to 7.3 and 9.8 individuals $/ \mathrm{m}^{2}$ in forest and gaps, respectively. Density remained stable between 2005 and 2006. In all three sample years, there were significantly more plots with substantial cover $(>50 \%$ of plot) of grasses or sedges in gaps than closed-canopy sites $(P<0.0001)$, but there were no significant differences among shrub treatments.

\section{Resource availability}

Overstory $\left(F_{1,2}=2021, P=0.0011\right)$ and shrub $\left(F_{3,100}\right.$ $=5.77, P=0.0011)$ treatments strongly influenced light availability (Fig. 1). Average light availability was $60.0 \%$ transmittance $(\% \mathrm{~T})$ in gaps and $11.8 \% \mathrm{~T}$ in closedcanopy sites. There was no overstory by shrub treatment 


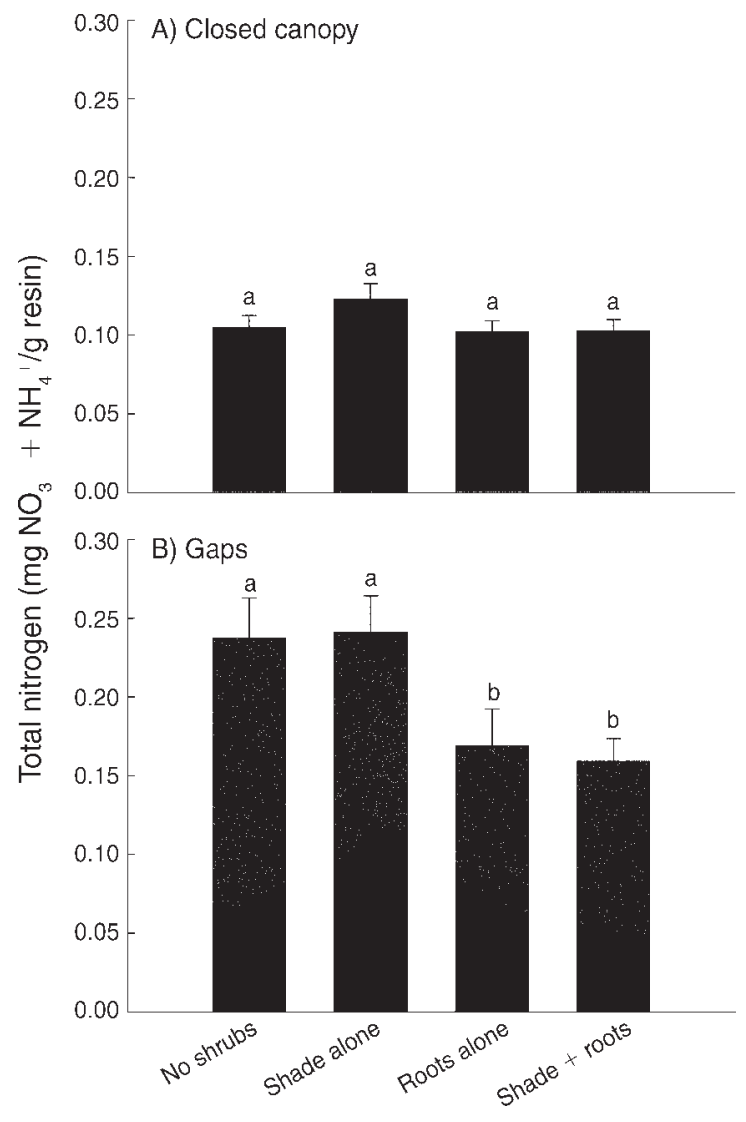

FIG. 2. Nitrogen availability (mean $+\mathrm{SE}$ ) measured (using ion exchange resin methods) as available $\mathrm{NO}_{3}{ }^{-}+\mathrm{NH}_{4}{ }^{+}(\mathrm{mg} \mathrm{N} /$ $\mathrm{g}$ resin) in four experimental shrub manipulations in (A) closed canopy and (B) centers of 0.3-ha gaps in red pine forest in northern Minnesota, USA. Experimental manipulations include shrub removal by clipping (shrubs absent), shrub removal by clipping and addition of shade cloth (shade alone), tieback of shrubs (roots alone), and unmanipulated shrubs (shade + roots). Within each panel, bars with different letters are significantly different using contrasts $(P<0.05)$.

interaction. Regardless of overstory conditions, complete shrub removal plots had significantly higher light availability than the shade alone and shade + roots treatments (Tukey HSD $\alpha=0.05$ ). The roots alone treatment was intermediate, reflecting the inability of the tieback approach to fully remove shading by surrounding shrub vegetation.

Overstory $\left(F_{1,3}=17.5, P<0.0249\right)$ and shrub $\left(F_{3,146}\right.$ $=3.43, P=0.0187)$ treatments strongly influenced total resin available $\mathrm{N}$ (Fig. 2). Average $\mathrm{N}$ in gaps (0.202 \pm $0.01 \mathrm{mg} / \mathrm{g}$; mean $\pm \mathrm{SE}$ ) was almost twice as high as in closed-canopy sites $(0.108 \pm 0.01 \mathrm{mg} / \mathrm{g})$. Treatments without shrub roots had significantly higher $\mathrm{N}$ availability than treatments with roots (Student's $t$ test at $\alpha=$ 0.05).

Overstory $\left(F_{1,3}=21.93, P<0.0185\right)$ treatments strongly influenced total resin available $\mathrm{P}$. Average $\mathrm{P}$ in gaps $(0.152 \pm 0.01 \mathrm{mg} / \mathrm{g})$ was almost twice as high as in closed-canopy sites $(0.079 \pm 0.01 \mathrm{mg} / \mathrm{g})$. The shrub treatment was marginally significant $\left(F_{3,143}=2.72, P=\right.$ $0.05)$; however, treatments without shrub roots did not differ from treatments with roots (Student's $t$ at $\alpha=$ $0.05)$.

\section{Survival}

In the full proportional hazards model, overstory treatment, shrub treatment, and species were all highly significant as main effects and there were significant interactions as well (Table 1). Overstory treatment significantly affected survival, but the direction of response differed among species (interaction $P<$ 0.0001 ) and was dependent on shrub treatment (interaction $P<0.0001$ [Table 1, Fig. 3]).

There were significant overstory $\times$ shrub treatment interactions for jack pine $\left(\chi^{2}=9.42, \mathrm{df}=3, P=0.0242\right)$, red maple $\left(\chi^{2}=13.5, \mathrm{df}=3, P=0.0037\right)$, and paper birch $\left(\chi^{2}=12.1, \mathrm{df}=3, P=0.0069\right)$, but the general trend was toward higher survival of red maple and paper birch in closed-canopy sites and higher survival of jack pine in gaps. For eastern white pine, $68 \%$ of seedlings in closedcanopy sites survived to the end of the experiment compared to $42 \%$ of seedlings planted in gaps $\left(\chi^{2}=\right.$ 29.08, $\mathrm{df}=1, P<0.0001)$. In contrast, red pine $\left(\chi^{2}=\right.$ $9.45, \mathrm{df}=1, P=0.0021)$ and northern red oak $\left(\chi^{2}=7.68\right.$, $\mathrm{df}=1, P=0.0056)$ seedlings had higher survival in gaps ( $17 \%$ and $45 \%$, respectively) compared to closed-canopy sites ( $4 \%$ and $28 \%)$. Given these interactions and the fact that the proportional hazards model neither characterizes differences among the four shrub treatments nor distinguishes among root vs. shade effects, in the remainder of this section, we present results of speciesspecific proportional hazards models (main effects $=$ overstory and shrub treatments) and Kaplan-Meier pairwise comparisons of shrub treatments for each species and overstory treatment.

Shrub treatments had significant impacts on survival and these varied among species and between overstory

TABLE 1. Proportional hazards model fit to survival data for seedlings of six species of trees grown under four experimental shrub manipulations in gaps and closed-canopy red pine forest in northern Minnesota, USA.

\begin{tabular}{lrrr}
\hline \hline \multicolumn{1}{c}{ Source } & df & $\begin{array}{c}\text { Likelihood } \\
\text { ratio } \chi^{2}\end{array}$ & \multicolumn{1}{c}{$P$} \\
\hline Species & 5 & 519.53 & $<\mathbf{0 . 0 0 0 1}$ \\
Overstory & 1 & 13.88 & $\mathbf{0 . 0 0 0 2}$ \\
Species $\times$ overstory & 5 & 152.39 & $<\mathbf{0 . 0 0 0 1}$ \\
Shrub & 3 & 10.94 & $\mathbf{0 . 0 1 2 1}$ \\
Species $\times$ shrub & 15 & 16.14 & 0.3727 \\
Overstory $\times$ shrub & 3 & 32.05 & $<\mathbf{0 . 0 0 0 1}$ \\
Species $\times$ overstory $\times$ shrub & 15 & 14.46 & 0.4913
\end{tabular}

Notes: Shrub treatments included shrub removal by clipping (shrubs absent), shrub removal by clipping and addition of shade cloth (shade alone), tieback of shrubs (roots alone), and unmanipulated shrubs (shade + roots). Seedlings were planted in May 2003 and harvested in September 2006. The six species of trees were Acer rubrum, Pinus strobus, Betula papyrifera, $P$. banksiana, $P$. resinosa, and Quercus rubra. Significance at $P \leq$ 0.05 is shown in boldface type. 
conditions (Fig. 3). In general, root interactions were negative for all species in the gap plots and neutral in closed-canopy forest, shade effects were positive or neutral in the gap plots, and shade effects were negative or neutral in closed-canopy forest. There were speciesspecific differences in these responses that were not well related to the shade tolerance of the species.

In red pine and red oak, shrub treatment effects were modest (a tendency for lower survival due to root interactions in gap plots) and did not differ between gaps and closed-canopy sites (Fig. 3). In the other four species, responses to shrub treatments differed in gap vs. forest interior plots. The overstory by shrub treatment interactions for red maple, paper birch, eastern white pine, and jack pine stemmed from differences in the strength and sometimes the direction of the shrub effect in gaps compared to closed canopy.

For jack pine, the net effect of shrubs was to decrease survival (Fig. 3A, B). In gaps, this was due entirely to negative effects of shrub roots, whereas in the closedcanopy forest negative shade effects predominated. In gaps, jack pine seedlings in plots without shrub roots had significantly higher survival than those in plots with shrub roots (Fig. 3B). In contrast, in the closed-canopy sites, jack pine survival was significantly higher in the unshaded plots than in shaded plots that simulated shrub shade (Fig. 3A).

For red maple, paper birch, and eastern white pine there was no net effect of the presence of shrubs: the shade + roots treatment was not different from the shrubs absent treatment (Fig. 3C-H). For these species, the net effect of shrubs masks the existence of both positive and negative interactions above and below ground. In gap plots, red maple seedling survival was highest in the shade alone treatment and lowest in the roots alone treatment with the shade + roots and the shrubs absent treatments intermediate, suggesting a facilitative effect of shrub shade (Fig. 3D). For paper birch, seedling survival in gaps was also highest in shade alone treatment and significantly lower in roots alone, shrubs absent, and shade + roots (Fig. 3F). In contrast, in the closed forest, treatments that included shade resulted in lowest birch survival (Fig. 3E). Finally, for eastern white pine, despite no significant overstory $\times$ shrub interaction in the species-specific model, pairwise comparisons suggest that in gap conditions the roots alone treatment had lower survival compared to the other three treatments. The trend in survival was similar to red maple, with highest survival in shade alone treatments, lowest survival in roots alone, and intermediate survival in the shade + roots and shrub absent treatments (Fig. 3H).

\section{Growth analysis}

The full model (omitting red pine that did not have survivors in all treatment combinations) showed that overstory treatment and species were significant as main effects, and that there were significant interactions for species $\times$ overstory treatment, species $\times$ shrub treatment, and species $\times$ overstory treatment $\times$ shrub treatment (Table 2). The species $\times$ overstory $\times$ shrub treatment interaction stemmed from differences in the strength of the shrub effect in gaps compared to closed-canopy sites and differences among species, especially within the gap sites. Since all interactions involving species were significant, the results below reflect separate analyses by species. We used contrasts to test hypotheses regarding specific overstory and understory treatment effects. We note that due to the nature of the model (i.e., $\log$ transformed) interactions are multiplicative rather than additive.

In general, seedlings grew significantly larger in gap plots. Average final size ranged from 6 to 40 times larger in gaps compared to closed-canopy sites. In the forest interior, seedlings ranged in size (mean $\pm \mathrm{SE}$ ) from 1.91 $\pm 0.16 \mathrm{~g}$ (red maple) to $5.45 \pm 0.33 \mathrm{~g}$ (white pine) (data not shown). There were no significant differences in growth among shrub treatments in closed-canopy sites for any species (data not shown). In gap sites, patterns of growth (Fig. 4) largely paralleled those of survival. There were strong negative effects of the presence of roots on growth of red maple, jack pine, and white pine. Jack and white pine seedlings in treatments with shrub roots present (shade + roots, roots alone) had significantly lower growth than seedlings in treatments without those roots (Fig. 4A, B). Red maple seedlings in the shade alone treatment were significantly larger than seedlings in all other treatments (Fig. 4C). Higher growth of red maple in shade alone treatments suggests a positive effect of shade, but only when roots are not present. For paper birch, red pine, and red oak, there was no significant effect of shrubs on growth (Fig. 4DF).

\section{Discussion}

Plant-plant interactions shape the structure, composition, and dynamics of forested ecosystems. The outcome of these interactions represents the net effect of positive and negative interactions occurring above and below ground. Shrubs play an important role in forest dynamics through complex interactions with tree seedlings. We found that shrubs either suppress or facilitate tree seedling survival and growth depending on species, source of interaction (e.g., above- or belowground) and ecological context (e.g., gap or forest interior). Our results largely support our hypotheses that interactions are important and that the nature of interactions (e.g., positive, negative, or neutral) differs above and below ground and with overstory condition. We found mixed evidence for the hypothesis that the nature of interactions differs with shade tolerance.

Most experiments that study understory plant interactions involve vegetation removal (e.g., Pecot et al. 2007, Devine and Harrington 2008). Such studies can identify net effects but fail to identify precise mechanisms that underlie plant-plant interactions. In this 

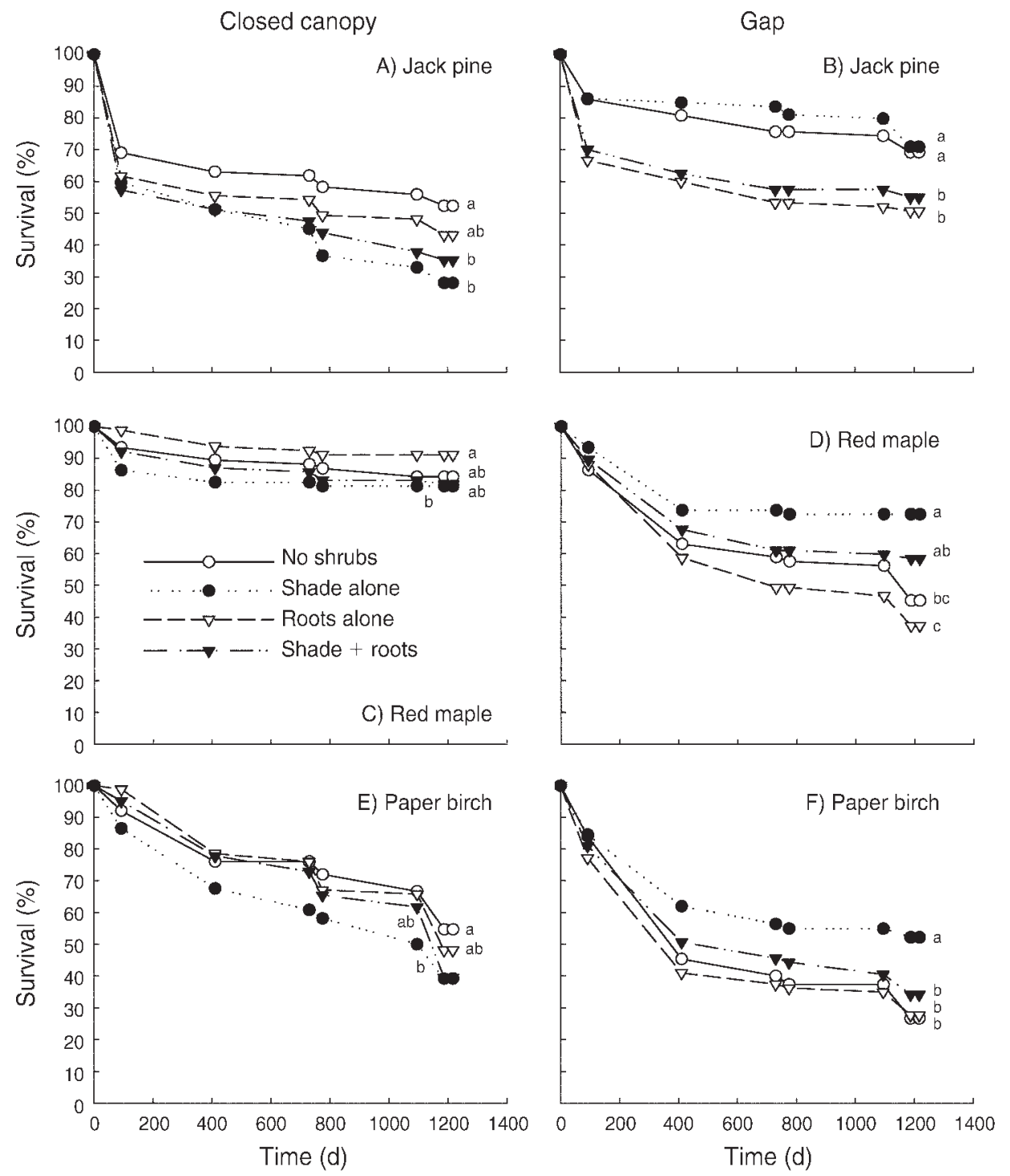

FIG. 3. Survival curves for seedlings of six species grown under four experimental manipulations in gaps and closed-canopy red pine forest in northern Minnesota, USA. Shrub treatments included shrub removal by clipping (shrubs absent), shrub removal by clipping and addition of shade cloth (shade alone), tieback of shrubs (roots alone) and unmanipulated shrubs (shade + roots). Species included Acer rubrum (red maple), Pinus strobus (eastern white pine), Betula papyrifera (paper birch), P. banksiana (jack pine), P. resinosa (red pine), and Quercus rubra (northern red oak). Note that triangles (both open and solid) correspond to treatments with roots present, and solid symbols (both triangles and circles) correspond to treatments with shade present. Survival curves with different lowercase letters are significantly different at the $P \leq 0.05$ level in Kaplan-Meier pairwise comparisons. Letters were placed at the point where the separation of the curves can be seen most clearly but represent overall differences among curves.

study, neutral net effects on several focal species masked positive effects of shrub shading and negative effects of shrub roots. Had we simply removed vegetation we would have concluded that there were no interactions between shrubs and seedlings except in the case of jack pine. Overall, separating above- and belowground interactions provided several key insights: (1) aboveground interactions depended strongly on species and ecological context, i.e., gaps or closed-canopy forest; they could be neutral, negative, or positive; (2) belowground interactions were neutral in the forest interior and negative in gaps regardless of species; and
(3) for several species negative interactions shifted from predominantly aboveground to predominantly belowground across the forest interior-gap contrast, supporting the idea that resource competition tracks the most limiting resource.

Light has long been considered the key resource influencing plant growth and survival in forest ecosystems, driving secondary succession and structuring community composition. Consistent with this idea, all of our study species grew larger in gaps and species differences in survival followed expectations based on shade tolerance. More shade-intolerant species (e.g., red 

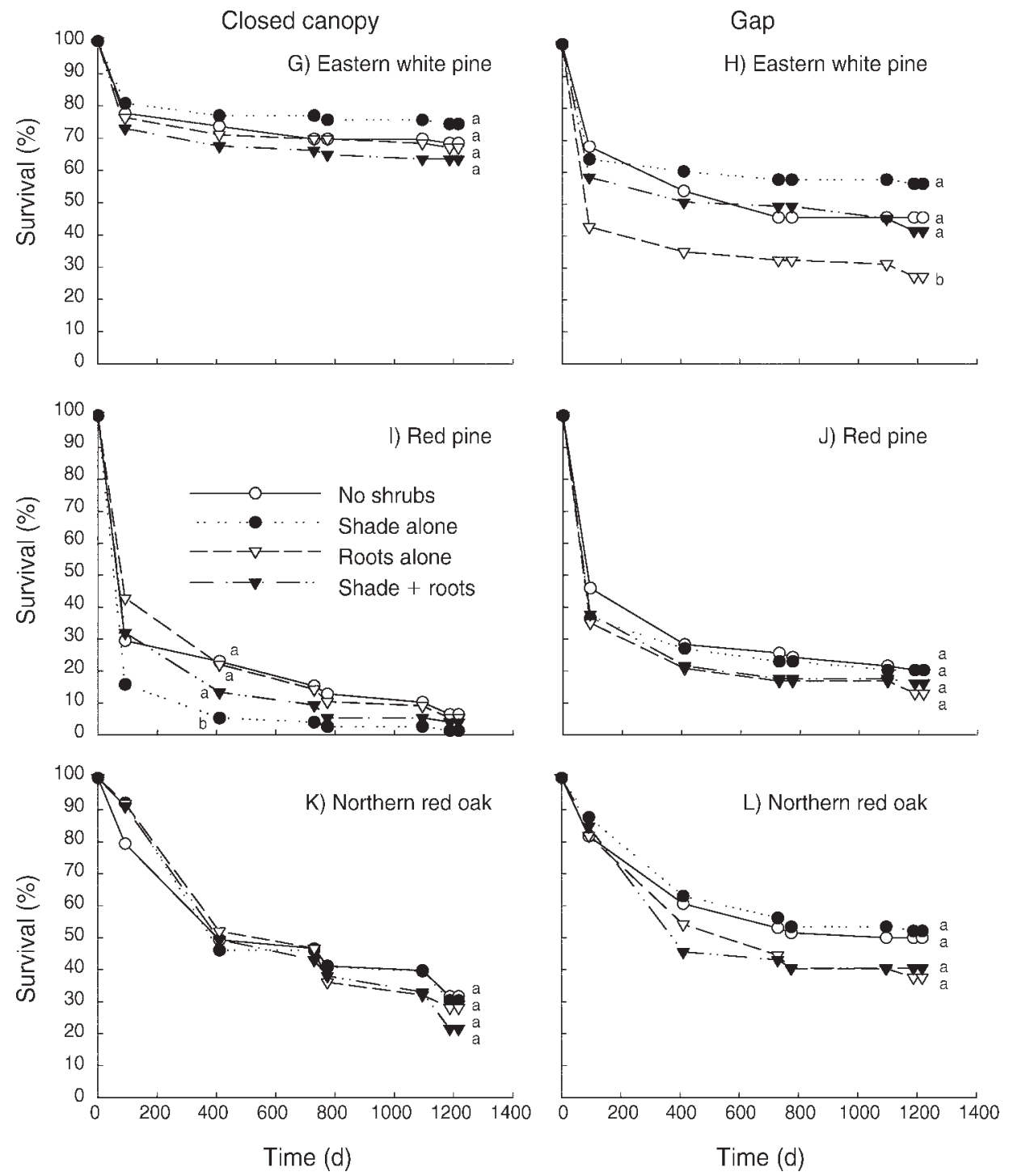

Fig. 3. Continued.

and jack pine) had higher survival in gaps, whereas more shade-tolerant species (e.g., red maple and white pine) had lower survival in gaps than in the forest interior. Although light and nutrient availability covaried between forest interiors and gaps, greater growth in gaps was likely due to greater light availability because growth in gaps was higher even in plots with similar levels of $\mathrm{N}$ availability to forest interior (Figs. 3 and 4). Beyond this general trend, the impact of shrub shade and roots is more complex, with belowground resources playing an important role.

\section{Belowground interactions in forest gaps}

Knowledge of belowground interactions in forests is poor because they are difficult to study. The focus has been on belowground competitive interactions (Coomes and Grubb 2000); however, facilitative interactions have also received some attention (Cater and Chapin 2000, Boyden et al. 2005, Heinemann and Kitzberger 2006, Pecot et al. 2007). Studies vary immensely in the extent of evidence for belowground competition (Ostertag 1998, Lewis and Tanner 2000, Ricard et al. 2003). Coomes and Grubb (2000) proposed that belowground competition is more likely in resource-poor forests than in resource-rich forests, consistent with belowground resources limiting growth and survival when nutrient availability is very low and when light limitation is considerable, but not extreme (Walters and Reich 1996, 2000). Our results from a moderately open canopy forest on sandy, nutrient-poor soils support this view. Belowground interactions between shrubs and tree seedlings, though largely neutral in the forest interior, were 
TABLE 2. ANCOVA model results for average aboveground biomass ( $\log _{10}$-transformed) of seedlings of six species grown under four experimental shrub manipulations in gaps and closed-canopy red pine forest in northern Minnesota, USA.

\begin{tabular}{lcccr}
\hline \hline \multicolumn{1}{c}{ Source } & $\mathrm{df}_{\text {num }}$ & $\mathrm{df}_{\text {den }}$ & $F$ & \multicolumn{1}{c}{$P$} \\
\hline Species & 4 & 946 & 134.9 & $<\mathbf{0 . 0 0 0 1}$ \\
Overstory & 1 & 6.63 & 151.7 & $<\mathbf{0 . 0 0 0 1}$ \\
Shrub & 3 & 232 & 2.52 & 0.0585 \\
Species $\times$ overstory & 4 & 944 & 28.4 & $<\mathbf{0 . 0 0 0 1}$ \\
Species $\times$ shrub & 12 & 947 & 2.72 & $\mathbf{0 . 0 0 1 3}$ \\
Overstory $\times$ shrub & 3 & 231 & 1.66 & 0.1757 \\
Species $\times$ overstory $\times$ shrub & 12 & 947 & 2.11 & $\mathbf{0 . 0 1 4 6}$ \\
Log $_{10}$ (initial seedling mass) & 1 & 958 & 122.9 & $<\mathbf{0 . 0 0 0 1}$
\end{tabular}

Notes: Experimental shrub treatments included shrub removal by clipping (shrubs absent), shrub removal by clipping and addition of shade cloth (shade alone), tieback of shrubs (roots alone), and unmanipulated shrubs (shade + roots). The six species of trees were Acer rubrum, Pinus strobus, Betula papyrifera, $P$. banksiana, $P$. resinosa, and Quercus rubra. Significance at $P \leq 0.05$ is shown in boldface type.

overwhelmingly negative in gaps. Among pine ecosystems, our area was neither particularly impoverished nor open (Palik et al. 2003, Bird 2005). Indeed, longleaf pine ecosystems are often savanna-like with more open canopies (Palik et al. 2003). Our soils were richer than the deep coarse outwash stands that support pine barrens (Anderson et al. 1999). While our study supports the notions that competition for a given resource is more intense when that resource is more limiting, and that ecophysiology of species influences the outcome of interactions (Coomes and Grubb 2000, Maestre et al. 2009), we note that the literature on plant-plant interactions contains conflicting results about intensity of species interactions on rich vs. poor sites (Coomes and Grubb 2000). Comparative manipulative studies across soil resource gradients would be useful to better understand the prevalence of belowground competition.

Shrub roots may have reduced seedling growth and survival due to belowground resource competition or interference for space (Messier et al. 2009). The significant reduction in total nitrogen availability in plots with shrub roots present supports the hypothesis that resource competition was the dominant negative interaction. We did not measure water availability, so we cannot distinguish whether root effects were due to competition for water or nutrients. Relatively low availability of water and nutrients in sandy soils may explain reduced survival and growth in the presence of roots. Alternatively, litter inputs in plots with roots may have altered soil conditions such as $\mathrm{pH}$. Hazel litter is rich in calcium, which could increase the $\mathrm{pH}$ (Tappeiner and Alm 1972, Tappeiner and John 1973), such that we might expect positive effects on growth in shade + roots treatments, but this was not the case.

Jack pine, a dominant tree of boreal forests, showed the most dramatic evidence for negative belowground interactions. Shade-intolerant jack pine regenerates in the open conditions that follow stand-replacing fires and is common on sandy, resource-poor soils (Burns and Honkala 1990:877). Twentieth century fire suppression has led to decline in jack pine at the southern edge of its range, where it now largely regenerates in clearcuts, if at all. Forest managers often apply herbicide to control "competing" vegetation and enhance regeneration of jack pine in these otherwise open conditions, because such control results in higher survival and more rapid growth (Benzie 1977). Based on the very low shade tolerance of jack pine, we expected that the effect of vegetation removal would be release from shade. Our experiment points to root competition as the more likely explanation. Our results suggest that jack pine can respond strongly to increased belowground resources in dry, resource-poor soils. Furthermore, escape from shrub shading through vertical growth may not alleviate the negative belowground effects of shrubs on growth and survival.

For jack pine, negative interactions shifted from predominantly belowground in gaps to predominantly aboveground in the forest interior, where the additional shade cast by shrubs limited jack pine survival. The strong shift in the nature of shrub-jack pine interactions fits predictions based on the relative limitation by resources, with aboveground resources more limiting in shade and belowground resources more limiting in the open (Bloom et al. 1985, Tilman 1985, Givnish 1988).

Lack of belowground interactions with shrubs in the forest interior may be due to canopy trees (Devine and Harrington 2008). Trenching and fertilization experiments that test whether adult trees are competitors with understory vegetation and tree seedlings indicate that both of the latter increase in productivity and survival when released from belowground competition with canopy trees (Riegel et al. 1992, Lewis and Tanner 2000, Lindh et al. 2003, Tanner and Barberis 2007, Devine and Harrington 2008; but see Pecot et al. 2007). Our treatments did not exclude canopy tree roots, instead focusing on the impacts of shrubs as additional neighbors for tree seedlings. Shrub treatments did not differ in nutrient availability, suggesting that shrub effects on belowground resources were small compared to overstory trees. The low impact of shrubs on soil resource availability is best explained by canopy suppression of shrub resource uptake rather than suppression of shrub abundance, since shrub abundance was similar in forest interior and gaps.

\section{Facilitation in gaps}

Whereas belowground interactions were overwhelmingly negative in gaps, aboveground interactions were neutral or positive (Figs. 3B, F, H, and 4C). Facilitation is an important component of species interactions in arid and semiarid systems (e.g., Flores and Jurado 2003, Pugnaire et al. 2004, Armas and Pugnaire 2005, GomezAparicio et al. 2005), but is less commonly found in forests (Cater and Chapin 2000, Boyden et al. 2005, 

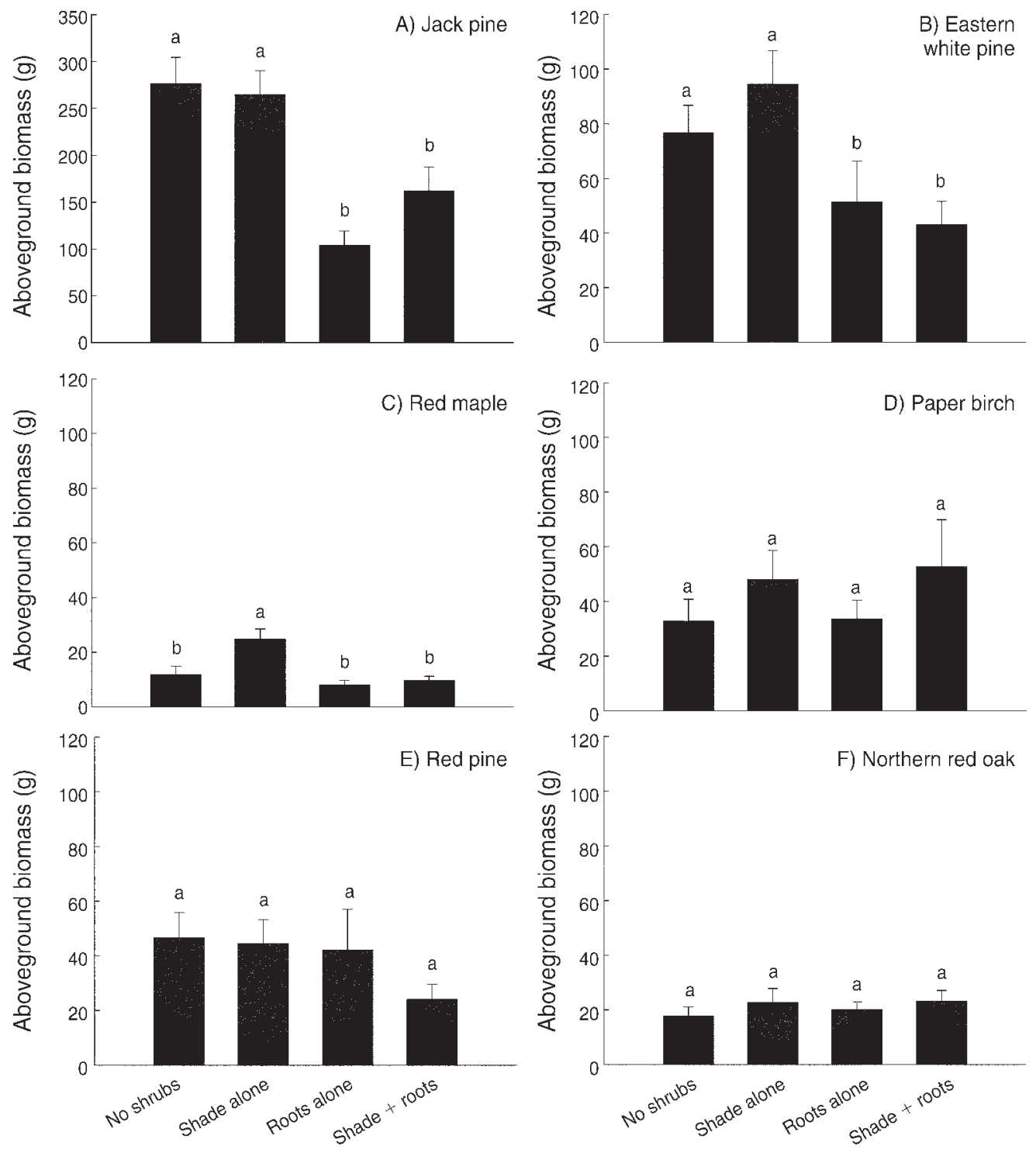

FIG. 4. Aboveground biomass (mean $+\mathrm{SE}$ ) after four growing seasons of seedlings of six species grown under four experimental manipulations in 0.3-ha gaps in red pine forest in northern Minnesota, USA. Species included are Acer rubrum (red maple), Pinus strobus (eastern white pine), Betula papyrifera (paper birch), P. banksiana (jack pine), P. resinosa (red pine), and Quercus rubra (northern red oak). Data for seedling growth in closed canopy is not presented (no significant differences among shrub treatments). Experimental treatments included shrub removal by clipping (shrubs absent), shrub removal by clipping and addition of shade cloth (shade alone), tieback of shrubs (roots alone), and unmanipulated shrubs (shade + roots). Within each panel, bars with different lowercase letters are significantly different using contrasts $(P<0.05)$.

Heinemann and Kitzberger 2006, Pecot et al. 2007). Mechanisms of facilitation include amelioration of microclimate and enhancement of resource availability. The facilitative effect of shade in our study is likely the result of microclimate alteration such as reduced air and soil surface temperature extremes, increased relative humidity, reduced VPD at leaf surface, or decreased excess irradiance. Aboveground plant parts could also shelter seedlings from large herbivores. However, since we protected our seedlings from deer browsing, the last is an unlikely cause for the patterns observed. We hypothesized that facilitation would be most likely for shade-tolerant species, reflecting the negative effects of excess irradiance on species whose photosynthetic rates are likely to saturate at relatively low light levels. This hypothesis was supported in part. Survival of our two most shade-tolerant species, red maple and white pine, was facilitated by shrub shade. However, survival of paper birch, one of our more intolerant species, was also facilitated by shrub shade. It may be that amelioration of the moisture environment is also an important aspect of facilitation, as these three species were the least 


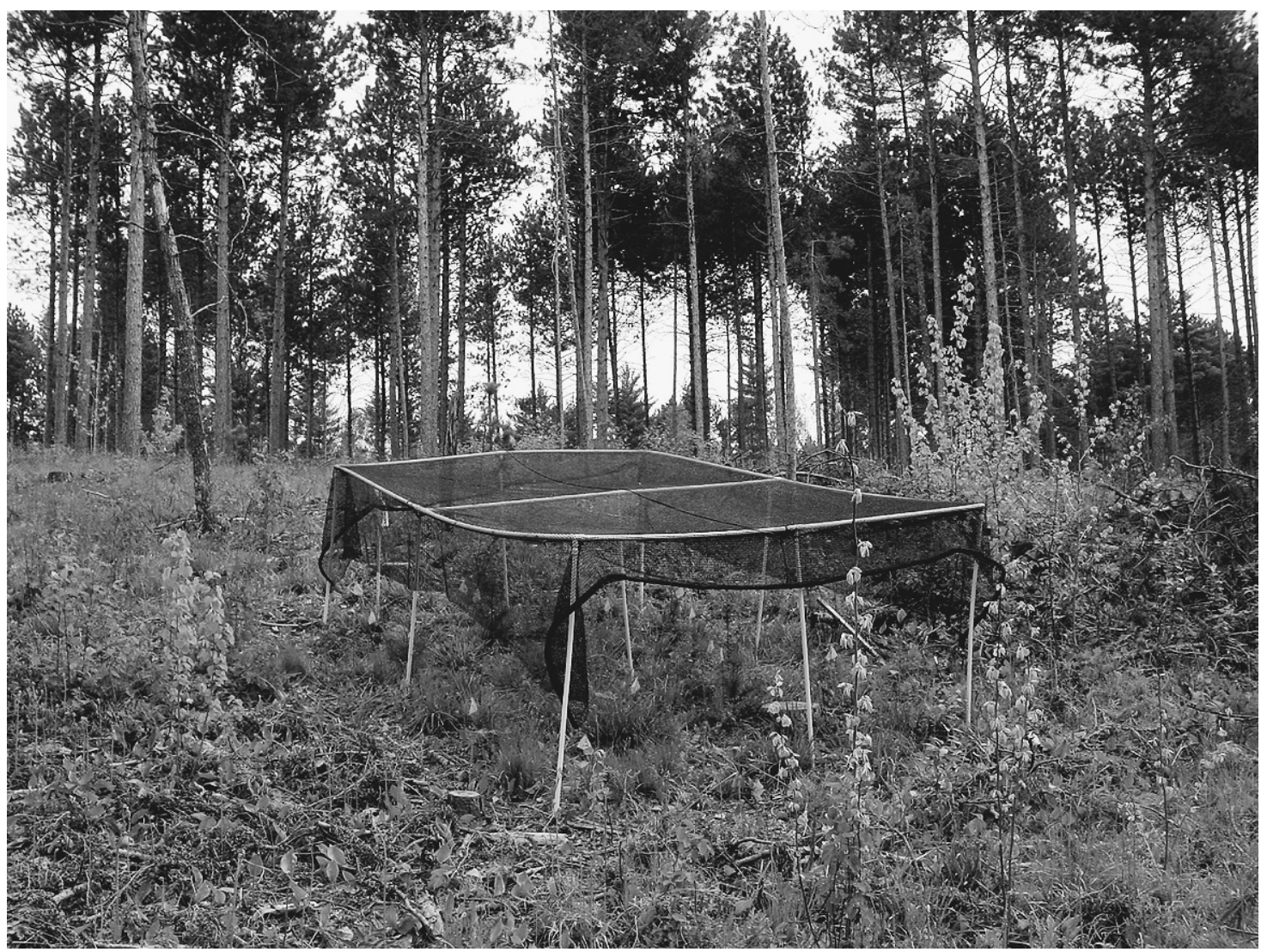

Plate 1. Shade structure used to study the effect of aboveground shading on tree seedling growth and survival. The structure was located in the center of an experimental gap in a red pine forest in north central Minnesota, USA. Photo credit: R. A. Montgomery.

drought tolerant of the six species studied (Niinemets and Valladares 2006).

\section{Caveats}

As with all manipulative experiments, our treatments may have had unintended and/or undocumented effects. We assume that greater potential nutrient availability in plots without shrub roots was due to reduced uptake and use of nutrients by shrubs. There are several other explanations. Greater $\mathrm{N}$ may have occurred due to enhanced nutrient supply via root decay; however, in most trenching experiments these inputs are thought to be relatively small (Coomes and Grubb 2000). Alternatively, removal of shrubs in shrubs absent plots may have increased soil surface temperatures, increasing $\mathrm{N}$ mineralization. However, similar increases in soil surface temperature might be expected in roots alone plots where vegetation is tied back, exposing the soil surface. In those plots, we found no evidence of increased $\mathrm{N}$ availability. Where shrubs were clipped (shade alone and shrubs absent), vegetation removal may have reduced litter inputs into plots. Hazel can contribute almost onequarter of the litter inputs in red pine forests, and that litter is higher in various nutrients than pine litter (e.g., N, P, K, Ca [Tappeiner and Alm 1972, Tappeiner and John 1973]). Reduced litter inputs could lead to lower nutrient availability, but we found instead that plots without hazel had higher nutrient levels than those with hazel.

Mortality was not constant over time, and we were unable to link this temporal heterogeneity to interannual variation in climate (data not shown). The high mortality of several species during the first summer suggests transplant shock. Since surviving seedlings show growth differences that strongly vary with shrub treatments, largely follow the same pattern as the survival effect, and were statistically related to shrub treatments, we believe that survival differences were influenced by shrub interactions independent of transplant shock. Finally, we found extremely high mortality of red pine across all treatments. This mortality was not related to the experiment, but rather resulted from infection of these seedlings with shoot blights caused by Diplodia spp. and Sirococcus conigenus (M. Ostry, personal communication). 


\section{Conclusions}

In summary, shrubs affect tree regeneration, forest dynamics, and composition through positive and negative effects of above- and belowground interactions. Shrubs can either facilitate or suppress tree seedling survival and growth depending on the ecological context (gaps or closed-canopy forest) and the species involved. Shrubs seem particularly important in gaps where roots had negative impacts on all species and shoots had neutral effects on some species and positive impacts on others. Separation of above- and belowground interactions is essential to understand mechanisms of interaction between shrubs and seedlings. Experiments can attribute net effects of shrubs to above- and belowground components of interactions, revealing that neutral net effects can result from opposing above- and belowground effects, i.e., positive effects of shrub shade, balanced by negative effects of shrub roots.

More studies that independently manipulate the above- and belowground environment are needed if we are to understand mechanisms of plant-plant interactions. Outcomes of plant-plant interactions vary with the nature of resource and nonresource (e.g., temperature) limitation and ecophysiology of the species involved (Maestre et al. 2009). Simple generality, a scientific goal, may be elusive, and advances in ecological theory should consider the existence of simultaneous positive and negative interactions that vary with ecological context and species (Bruno et al. 2003, Lortie et al. 2004, Brooker et al. 2008).

\section{ACKNOWLEDGMENTS}

We thank Christel Kern, Kathryn Lang, Susan Barrott, and Suzie Boyden for field crew supervision and data organization; Dave Upgren for providing conifer seedlings and for organizing fall browse control; Doris Nelson for soil nutrient analyses; Mark Holland for statistical consulting; Naomi Worm, Cece Dahlstrom, Kathryn Smith, Bill Hakala, Andrea Dierich, Mike Reinikainen, Chris Gronewold, Michael Dyste, Erin Baumgart, and numerous members of short-term field crews for the bulk of field data collection and their enthusiasm in the face of ticks, mosquitoes, black flies, and brush. Funding was provided by USDA NRI CREES Award No. 2006-35101-17061, the USDA Forest Service Northern Research Station, the Wilderness Research Foundation, and the Minnesota Agricultural Experiment Station MIN-42-074.

\section{Literature Cited}

Alban, D. H. 1974. Soil variation and sampling intensity under red pine and aspen in Minnesota. General Technical Report NC-106. USDA Forest Service North Central Forest Experiment Station, St. Paul, Minnesota, USA.

Anderson, R. C., J. S. Fralish, and J. M. Baskin, editors. 1999. Savannas, barrens and rock outcrop plant communities of North America. Cambridge University Press, Cambridge, UK.

Armas, C., and F. I. Pugnaire. 2005. Plant interactions govern population dynamics in a semi-arid plant community. Journal of Ecology 93:978-989.

Atwell, R. C., L. A. Schulte, and B. J. Palik. 2008. Songbird response to experimental retention harvesting in red pine (Pinus resinosa) forests. Forest Ecology and Management 255:3621-3631.
Augspurger, C. K., and C. K. Kelly. 1984. Pathogen mortality of tropical tree seedlings: experimental studies of the effects of dispersal distance, seedling density and light conditions. Oecologia 61:211-217.

Bartemucci, P., C. Messier, and C. D. Canham. 2006. Overstory influences on light attenuation patterns and understory plant community diversity and composition in southern boreal forests of Quebec. Canadian Journal of Forest Research 36:2065-2079.

Beaudet, M., and C. Messier. 1998. Growth and morphological responses of yellow birch, sugar maple, and beech seedlings growing under a natural light gradient. Canadian Journal of Forest Research 28:1007-1015.

Belsky, A. J. 1994. Influences of trees on savanna productivity: tests of shade, nutrients, and tree-grass competition. Ecology 75:922-932.

Benzie, J. W. 1977. Manager's handbook for jack pine in the north central states. USDA Forest Service North Central Forest Experiment Station General Technical Report NC-32. St. Paul, Minnesota, USA.

Bertness, M. D., and R. Callaway. 1994. Positive interactions in communities. Trends in Ecology and Evolution 9:191-193.

Bird, S. 2005. The role of spatial pattern in controlling forest dynamics. Dissertation. Colorado State University, Fort Collins, Colorado, USA.

Bloom, A. J., F. S. Chapin, III, and H. A. Mooney. 1985. Resource limitation in plants - an economic analogy. Annual Review of Ecology and Systematics 16:363-392.

Boyden, S., D. Binkley, and R. Senock. 2005. Competition and facilitation between Eucalyptus and nitrogen-fixing Falcataria in relation to soil fertility. Ecology 86:992-1001.

Boyden, S. B., P. B. Reich, K. J. Puettmann, and T. R. Baker. 2009. Effects of density and ontogeny on size and growth ranks of three competing tree species. Journal of Ecology 97: 277-288.

Brokaw, N. V. L. 1985. Gap-phase regeneration in a tropical forest. Ecology 66:682-687.

Brooker, R. W., et al. 2008. Facilitation in plant communities: the past, the present, and the future. Journal of Ecology 96: $18-34$.

Bruno, J. F., J. J. Stachowicz, and M. D. Bertness. 2003. Inclusion of facilitation into ecological theory. Trends in Ecology and Evolution 18:119-125.

Burns, R. M., and B. H. Honkala. 1990. Silvics of North America. USDA Forest Service Agriculture Handbook 654, Washington, D.C., USA.

Burslem, D. F. R. P., P. J. Grubb, and I. M. Turner. 1995. Responses to nutrient addition among shade-tolerant tree seedlings of lowland tropical rain forest in Singapore. Journal of Ecology 83:113-122.

Callaway, R. M. 1995. Positive interactions among plants. Botanical Review 61:306-349.

Callaway, R. M., N. M. Nadkarni, and B. E. Mahall. 1991. Facilitation and interference of Quercus douglasii on understory productivity in central California. Ecology 72:14841499.

Callaway, R. M., and W. M. Ridenour. 2004. Novel weapons: invasive success and the evolution of increased competitive ability. Frontiers in Ecology and the Environment 2:436443.

Callaway, R. M., and L. R. Walker. 1997. Competition and facilitation: a synthetic approach to interactions in plant communities. Ecology 78:1958-1965.

Casper, B. B., and R. B. Jackson. 1997. Plant competition underground. Annual Review of Ecology and Systematics 28: 545-570.

Cater, T. C., and F. S. Chapin. 2000. Differential effects of competition or microenvironment on boreal tree seedling establishment after fire. Ecology 81:1086-1099.

Chen, Y. J., F. Bongers, K. F. Cao, and Z. Q. Cai. 2008. Above- and below-ground competition in high and low 
irradiance: tree seedling responses to a competing liana Byttneria grandifolia. Journal of Tropical Ecology 24:517524.

Clark, D. B., and D. A. Clark. 1991. The impact of physical damage on canopy tree regeneration in tropical rain forest. Journal of Ecology 79:447-457.

Connell, J. H. 1983. On the prevalence and relative importance of interspecific competition: evidence from field experiments. American Naturalist 122:661-696.

Connell, J. H. 1990. Apparent vs. "real" competition in plants. Pages 9-26 in J. B. Grace and D. Tilman, editors. Perspectives on plant competition. Blackburn Press, Caldwell, New Jersey, USA.

Coomes, D. A., and P. J. Grubb. 1998. Responses of juvenile trees to above- and belowground competition in nutrientstarved Amazonian rain forest. Ecology 79:768-782.

Coomes, D. A., and P. J. Grubb. 2000. Impacts of root competition in forests and woodlands: a theoretical framework and review of experiments. Ecological Monographs 70: 171-207.

Davis, M. A., K. J. Wrage, and P. B. Reich. 1998. Competition between tree seedlings and herbaceous vegetation: support for a theory of resource supply and demand. Journal of Ecology 86:652-661.

Devine, W. D., and T. B. Harrington. 2008. Belowground competition influences growth of natural regeneration in thinned Douglas-fir stands. Canadian Journal of Forest Research 38:3085-3097.

Dickie, I. A., S. A. Schnitzer, P. B. Reich, and S. E. Hobbie. 2005. Spatially disjunct effects of co-occurring competition and facilitation. Ecology Letters 8:1191-1200.

Dillenburg, L. R., D. F. Whigham, A. H. Teramura, and I. N. Forseth. 1993. Effects of belowground and aboveground competition from the vines Lonicera japonica and Parthenocissus quinquefolia on the growth of the tree host Liquidambar styraciflua. Oecologia 93:48-54.

Fagan, M. E., and D. R. Peart. 2004. Impact of the invasive shrub glossy buckthorn (Rhamnus frangula L.) on juvenile recruitment by canopy trees. Forest Ecology and Management 194:95-107.

Farris-Lopez, K., J. S. Denslow, B. Moser, and H. Passmore. 2004. Influence of a common palm, Oenocarpus mapora, on seedling establishment in a tropical moist forest in Panama. Journal of Tropical Ecology 20:429-438.

Flores, J., and E. Jurado. 2003. Are nurse-protege interactions more common among plants from arid environments? Journal of Vegetation Science 14:911-916.

George, L. O., and F. A. Bazzaz. 1999a. The fern understory as an ecological filter: emergence and establishment of canopytree seedlings. Ecology 80:833-845.

George, L. O., and F. A. Bazzaz. 1999b. The fern understory as an ecological filter: growth and survival of canopy-tree seedlings. Ecology 80:846-856.

Givnish, T. J. 1988. Adaptation to sun and shade: a whole-plant perspective. Australian Journal of Plant Physiology 15:6392.

Goldberg, D. E. 1987. Neighborhood competition in an oldfield plant community. Ecology 68:1211-1223.

Gomez-Aparicio, L., F. Valladares, R. Zamora, and J. L. Quero. 2005. Response of tree seedlings to the abiotic heterogeneity generated by nurse shrubs: an experimental approach at different scales. Ecography 28:757-768.

Harrington, T. B. 2006. Five-year growth responses of Douglas fir, western hemlock, and western red cedar seedlings to manipulated levels of overstory and understory competition. Canadian Journal of Forest Research 36:2439-2453.

Heinemann, K., and T. Kitzberger. 2006. Effects of position, understorey vegetation and coarse woody debris on tree regeneration in two environmentally contrasting forests of north-western Patagonia: a manipulative approach. Journal of Biogeography 33:1357-1367.
Holt, R. D. 1977. Predation, apparent competition, and structure of prey communities. Theoretical Population Biology 12:197-229.

Horsley, S. B. 1993. Mechanisms of interference between hayscented fern and black cherry. Canadian Journal of Forest Research 23:2059-2069.

Janzen, D. H. 1970. Herbivores and the number of tree species in tropical forests. American Naturalist 104:501-528.

Kitajima, K. 1994. Relative importance of photosynthetic traits and allocation patterns as correlates of seedling shade tolerance of 13 tropical trees. Oecologia 98:419-428.

Klironomos, J. N. 2002. Feedback with soil biota contributes to plant rarity and invasiveness in communities. Nature 417:6770.

Lewis, S. L., and E. V. J. Tanner. 2000. Effects of above- and belowground competition on growth and survival of rain forest tree seedlings. Ecology 81:2525-2538.

Lindh, B. C., A. N. Gray, and T. A. Spies. 2003. Responses of herbs and shrubs to reduced root competition under canopies and in gaps: a trenching experiment in old-growth Douglas fir forests. Canadian Journal of Forest Research 33:2052 2057.

Lorimer, C. G., J. W. Chapman, and W. D. Lambert. 1994. Tall understorey vegetation as a factor in the poor development of oak seedlings beneath mature stands. Journal of Ecology 82: 227-237.

Lortie, C. J., R. W. Brooker, P. Choler, Z. Kikvidze, R. Michalet, F. I. Pugnaire, and R. M. Callaway. 2004. Rethinking plant community theory. Oikos 107:433-438.

Ludwig, F., T. E. Dawson, H. H. T. Prins, F. Berendse, and H. de Kroon. 2004. Below-ground competition between trees and grasses may overwhelm the facilitative effects of hydraulic lift. Ecology Letters 7:623-631.

Machado, J. L., and P. B. Reich. 1999. Evaluation of several measures of canopy openness as predictors of photosynthetic photon flux density in deeply shaded coniferdominated forest understory. Canadian Journal of Forest Research 29:1438-1444.

Machado, J. L., M. B. Walters, and P. B. Reich. 2003. Belowground resources limit seedling growth in forest understories but do not alter biomass distribution. Annals of Forest Science 60:319-330.

Maestre, F. T., S. Bautista, and J. Cortina. 2003. Positive, negative, and net effects in grass-shrub interactions in mediterranean semiarid grasslands. Ecology 84:3186-3197.

Maestre, F. T., R. M. Callaway, F. Valladares, and C. J. Lortie. 2009. Refining the stress-gradient hypothesis for competition and facilitation in plant communities. Journal of Ecology 97: 199-205.

Messier, C. 1993. Factors limiting early growth of western red cedar, western hemlock and sitka spruce seedlings on ericaceous-dominated clear-cut sites in coastal British Columbia. Forest Ecology and Management 60:181-206.

Messier, C., L. Coll, A. Poitras-Lariviere, N. Belanger, and J. Brisson. 2009. Resource and non-resource root competition effects of grasses on early- vs. late-successional trees. Journal of Ecology 97:548-554.

Messier, C., S. Parent, and Y. Bergeron. 1998. Effects of overstory and understory vegetation on the understory light environment in mixed boreal forests. Journal of Vegetation Science 9:511-520.

Montgomery, R. A. 2004. Effects of understory foliage on patterns of light attentuation near the forest floor. Biotropica 36:33-39.

Montgomery, R. A., and R. L. Chazdon. 2002. Light gradient partitioning by tropical tree seedlings in the absence of canopy gaps. Oecologia 131:165-174.

Niinemets, U., and F. Valladares. 2006. Tolerance to shade, drought, and waterlogging of temperate Northern Hemisphere trees and shrubs. Ecological Monographs 76:521547. 
Ostertag, R. 1998. Belowground effects of canopy gaps in a tropical wet forest. Ecology 79:1294-1304.

Palik, B., R. J. Mitchell, S. Pecot, M. Battaglia, and M. Pu. 2003. Spatial distribution of overstory retention influences resources and growth of longleaf pine seedlings. Ecological Applications 13:674-686.

Parent, S., and C. Messier. 1996. A simple and efficient method to estimate microsite light availability under a forest canopy. Canadian Journal of Forest Research 26:151-154.

Pecot, S. D., R. J. Mitchell, B. J. Palik, E. B. Moser, and J. K. Hiers. 2007. Competitive responses of seedlings and understory plants in longleaf pine woodlands: separating canopy influences above and below ground. Canadian Journal of Forest Research 37:634-648.

Pugnaire, F. I., C. Armas, and F. Valladares. 2004. Soil as a mediator in plant-plant interactions in a semi-arid community. Journal of Vegetation Science 15:85-92.

Pugnaire, F. I., and M. T. Luque. 2001. Changes in plant interactions along a gradient of environmental stress. Oikos 93:42-49.

Putz, F. E., and C. D. Canham. 1992. Mechanisms of arrested succession in shrublands: root and shoot competition between shrubs and tree seedlings. Forest Ecology and Management 49:267-275.

Ricard, J. P., C. Messier, S. Delagrange, and M. Beaudet. 2003. Do understory saplings respond to both light and belowground competition? a field experiment in a north-eastern American hardwood forest and a literature review. Annals of Forest Science 60:749-756.

Riegel, G. M., R. F. Miller, and W. C. Krueger. 1992. Competition for resources between understory vegetation and overstory Pinus ponderosa in northeastern Oregon. Ecological Applications 2:71-85.

Royo, A. A., and W. P. Carson. 2006. On the formation of dense understory layers in forests worldwide: consequences and implications for forest dynamics, biodiversity, and succession. Canadian Journal of Forest Research 36:13451362.

Schnitzer, S. A., M. E. Kuzee, and F. Bongers. 2005. Disentangling above- and below-ground competition between lianas and trees in a tropical forest. Journal of Ecology 93:1115-1125.
Schoener, T. W. 1983. Field experiments on interspecific competition. American Naturalist 122:240-285.

Scholes, R. J., and S. R. Archer. 1997. Tree-grass interactions in savannas. Annual Review of Ecology and Systematics 28: $517-544$.

Shirley, H. L. 1945. Reproduction of upland conifers in the Lake States as affected by root competition and light. American Midland Naturalist 33:537-612.

Tanner, E. V. J., and I. M. Barberis. 2007. Trenching increased growth, and irrigation increased survival of tree seedlings in the understorey of a semi-evergreen rain forest in Panama. Journal of Tropical Ecology 23:257-268.

Tappeiner, J. C., and A. A. Alm. 1972. Effect of hazel on nutrient composition of annual litter and forest floor in jack and red pine stands. Minnesota Forestry Research Notes 235: $1-4$.

Tappeiner, J. C., and H. H. John. 1973. Biomass and nutrient content of hazel undergrowth. Ecology 54:1342-1348.

Tilman, D. 1982. Resource competition and community structure. Princeton University Press, Princeton, New Jersey, USA.

Tilman, D. 1985. The resource-ratio hypothesis of plant succession. American Naturalist 125:827-852.

Toledo-Aceves, T., and M. D. Swaine. 2008. Above- and belowground competition between the liana Acacia kamerunensis and tree seedlings in contrasting light environments. Plant Ecology 196:233-244.

Valladares, F., J. Zaragoza-Castells, D. Sanchez-Gomez, S. Matesanz, B. Alonso, A. Portsmuth, A. Delgado, and O. K. Atkin. 2008. Is shade beneficial for Mediterranean shrubs experiencing periods of extreme drought and late-winter frosts? Annals of Botany 102:923-933.

Walters, M. B., and P. B. Reich. 1996. Are shade tolerance, survival, and growth linked? Low light and nitrogen effects on hardwood seedlings. Ecology 77:841-853.

Walters, M. B., and P. B. Reich. 2000. Seed size, nitrogen supply, and growth rate affect tree seedling survival in deep shade. Ecology 81:1887-1901.

Zou, C. B., P. W. Barnes, S. Archer, and C. R. McMurtry. 2005. Soil moisture redistribution as a mechanism of facilitation in Savanna tree-shrub clusters. Oecologia 145: $32-40$. 